\title{
The Modification Effect of Spatial Configuration and Openings on Natural Ventilation Performance Case Study: Betang House at Central Borneo
}

\author{
Bimantoro, A. A. \\ Post Graduate \\ Department of Architecture \\ Institut Teknologi Sepuluh Nopember \\ Surabaya, Indonesia \\ Samodra, F. X. T. B. \\ Lecturer \\ Department of Architecture \\ Institut Teknologi Sepuluh Nopember \\ Surabaya, Indonesia
}

\begin{abstract}
Traditional House is a house that recognized as climate responsive architecture. Some traditional houses that exist today have undergone changes in accordance with lifestyle and occupant activity. Such changes may result in a change in the performance of natural ventilation of the original house in the past. This research takes a case study of Betang Djaga Bahen House in Central Borneo. This house is Traditional House of Central Borneo (Betang house) which has been through various changes. This study aims to evaluate the natural ventilation of the current house and the effects of changes that occur from the original house to the condition of the existing house today. The experimental method in this study was assisted using ANSYS CFD 16.2. The result obtained from this study is that the current condition of betang home can be said to be comfortable where only about $8.2 \%$ need air movement in the room as physiological cooling. The experiments show that the current building model has the lowest Air Change per Hour ( $\mathrm{ACH}$ ) level but the value of air rate per person is considered the best, because of the different occupancy levels in the past. The traditional ventilation cannot increase the wind speed indoors significantly, which influences from the opening of the traditional ventilation is the change of openings inside the house that occur due to the absence of the ceiling.
\end{abstract}

Keywords- Traditional House; Natural Ventilation; Physiological Cooling.

\section{INTRODUCTION}

Traditional houses are recognized as climate responsive architecture. Many researcher reported the response in thermal. Fitriaty, et.al conducted research for traditional House in Celebes [1], Karyono et.al reported research at Uma Kbubu traditional house [2] and Alfred et.al at Niang house [3], both of them in East Nusa Tenggara. They concerned on material and design aspects, which influenced the indoor temperature, without considering the air flow resulted by window position and room configuration. Betang House is one of them, which characterized by opening at the gevel, called Rumbak Tahansengan. It seems to promote the potencies of lighting as well as ventilation

\author{
Ekasiwi, S. N. N. \\ Lecturer \\ Department of Architecture \\ Institut Teknologi Sepuluh Nopember \\ Surabaya, Indonesia \\ Damayanti, D.P. \\ Young Researcher \\ Research Station for Housing on Region II Denpasar \\ Ministry of Public Works and Housing \\ Denpasar, Indonesia
}

inside the room. Susanti et.al [4] reported research on daylighting of it. The study concludes that Rumbak Tahansengan can improve daylight distribution in building.

As the time progress, traditional houses began to be abandoned, some of which were renovated in accordance with the needs of residents or due to changes in function. One of the traditional houses that survive until now and through some renovations is Betang Djaga Bahen House (Fig. 1). It was originally Betang House which was first established by Djaga Bahen and undergone 5 times of renovations from 1933 until 1995. The renovations either change of space, roof, or openings. Spatial configuration changes cause not all spaces to have windward and leeward sides that directly face the outer space due to the formation of partitions, which cause the movement of the wind to be limited in some of the spaces. As a traditional house that uses natural ventilation as physiological cooling, this case must be studied further.

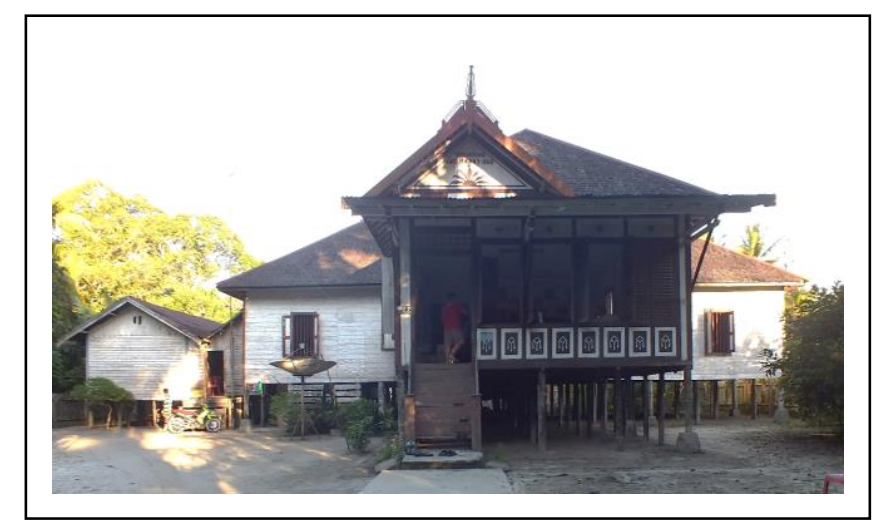

Fig. 1. Betang Djaga Bahen House

The previous research studies have discussed natural ventilation in traditional house, like at Minahasa [5]. Several studies have also been researched at Betang Djaga Bahen House regarding design changes [6], interior space [7] and 
natural lighting [4]. This paper reported the result of investigation of natural ventilation at Betang Djaga Bahen due to modifications that have occurred. It is hoped that transformation in spatial configuration and functions do not affect the value of the comfort requirement for the activities.

\section{THEORETICAL REVIEW}

High temperature along with high humidity are characteristic of tropical climate. In such condition, wind is required as aspect of physiological cooling. Samodra [8] reported that In lowland daytime, the urban building has a problem of lower wind speed for restoring thermal comfort with average minimum $1.5 \mathrm{~m} / \mathrm{s}$ wind speed requirement. In addition to physiological cooling, wind is also necessary to replace indoor air with fresh and healthier air [9], it is in accordance with the Air Change per Hour $(\mathrm{ACH})$ standard established by SNI 03-6572-2001 (Table 1.).

TABLE I. ACH REQUIREMENT
\begin{tabular}{|c|c|}
\hline Room & ACH \\
\hline Basement & $3-4$ \\
\hline Bedroom & $5-6$ \\
\hline Bathroom & $6-7$ \\
\hline Living Room & $6-8$ \\
\hline Kitchen & $7-8$ \\
\hline Laundry & $8-9$ \\
\hline
\end{tabular}

Physiological cooling can be interpreted as the need for air flow in the room to get thermal comfort. The required wind speed is called velocity comfort (vc), it can be calculated based on the following equation [10];

$$
\begin{aligned}
\mathrm{Vc}= & 0.15 *(\mathrm{DBT}-\mathrm{UCT}+(0.8 *((\mathrm{RH}-60) / 10))+ \\
& (0.55 *(\mathrm{MRT}-38) / 2.8))
\end{aligned}
$$

where:

$\mathrm{vc}=$ velocity comfort, minimum air movement for physiological cooling $(\mathrm{m} / \mathrm{s})$

DBT $=$ Dry Bulb Temperature $\left({ }^{0} \mathrm{C}\right)$

$\mathrm{UCT}=$ Upper Comfort Temperature $\left({ }^{0} \mathrm{C}\right)$

$\mathrm{RH}=$ Relative Humidity $(\%)$

MRT $=$ Mean Radiant Temperature $\left({ }^{0} \mathrm{C}\right)$

A good natural ventilation performance in dwelling houses in humid tropical climates requires openings of $50 \%$ of the total floor area [8]. A good opening position for physiological cooling is at the height of the human body $(100-150 \mathrm{~cm})$, while the inlet and outlet quantities of equal size will result in the highest average of wind speed [9].

\section{METHOD}

Experiment is used as the method of the study. It support with simulation on purpose to find a causal relationship of the change in space configuration and openings towards the performance of natural ventilation. Field measurements were made to record the natural ventilation performance of thermal comfort of the occupants. The results of the measurements will be simulated on ANSYS 16.2 CFD (Computational Fluid Dynamic) for verification and experimentation on Betang Djaga Bahen House. Experiments is performed on the simulation in the form of treatment on the configuration of space and openings in buildings.
Betang Djaga Bahen House has been transformed in 5 periods. It first change was in 1938 and keep changing until 1995. These changes can be seen in Table II.

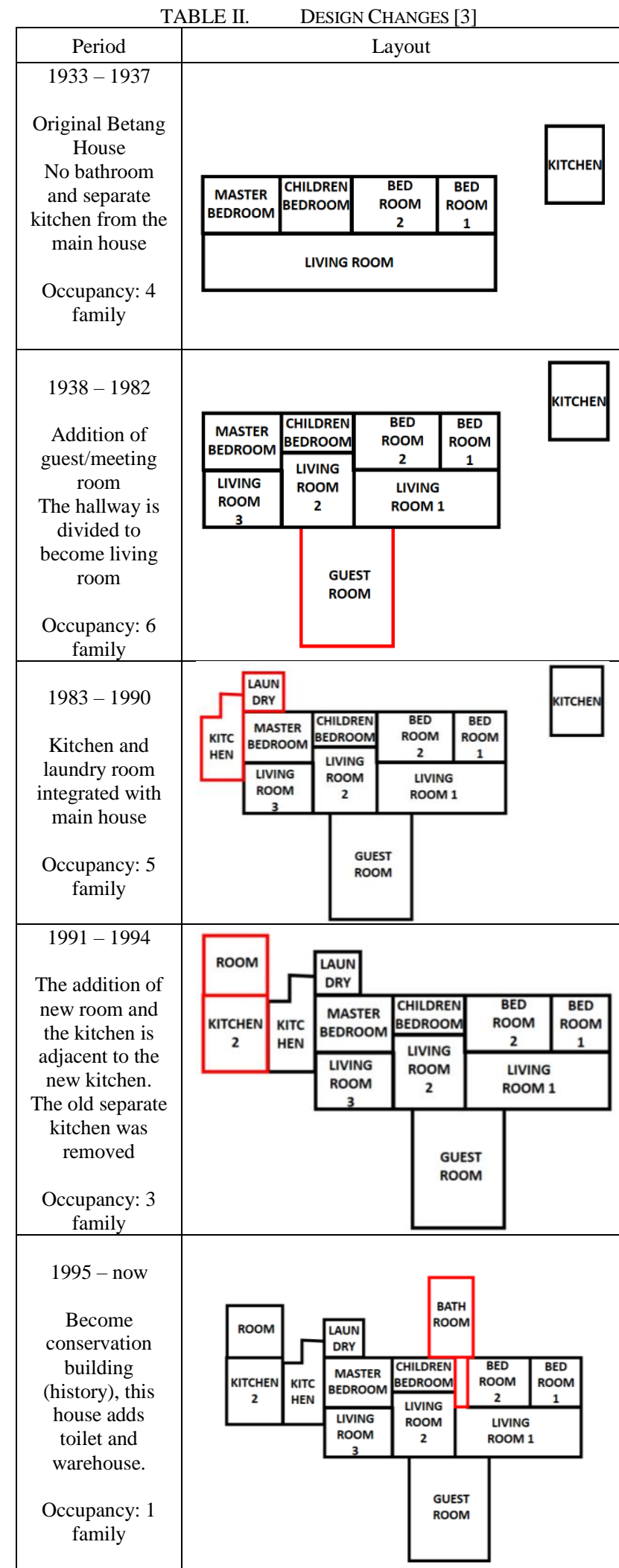

They characterized by the changes of WWR, the window position included the presence of Rumbak Tahansengan as well as ceiling. It can be seen in Table III and Table IV. 
TABLE III. 3D MODEL FOR EXPERIMENT

\begin{tabular}{|c|c|c|c|}
\hline & Period & WWR & 3D MODEL \\
\hline A & 2014 & $10,9 \%$ & \\
\hline B & 1991 & $11,85 \%$ & \\
\hline $\mathrm{C}$ & 1983 & $13,72 \%$ & \\
\hline D & 1938 & $14,60 \%$ & \\
\hline $\mathrm{E}$ & 1933 & $9,52 \%$ & \\
\hline $\mathrm{F}$ & 1933 & $9,62 \%$ & \\
\hline G & 2014 & $10,18 \%$ & \\
\hline
\end{tabular}

TABLE IV. MODEL DESCRIPTION

\begin{tabular}{|c|c|c|c|c|}
\hline \multirow{2}{*}{ Model } & \multirow{2}{*}{ Period } & \multicolumn{3}{|c|}{ Description } \\
\cline { 3 - 5 } & & Roof & Ceiling & $\begin{array}{c}\text { Rumbak } \\
\text { Tahansengan }\end{array}$ \\
\hline A & 2014 & Pitch roof & $\sqrt{ }$ & $\times$ \\
\hline B & 1991 & Pitch roof & $\sqrt{ }$ & $\times$ \\
\hline C & 1983 & Pitch roof & $\sqrt{ }$ & $\times$ \\
\hline D & 1938 & Pitch roof & $\sqrt{ }$ & $\times$ \\
\hline E & 1933 & Gable roof & $\times$ & $\sqrt{ }$ \\
\hline F & 1933 & Gable roof & $\times$ & $\times$ \\
\hline G & 2014 & Gable roof & $\times$ & $\sqrt{ }$ \\
\hline
\end{tabular}

The experiment concern on 4 discuccion; Experiment 1 discuss the building tranformation to climate or wind speed in a given year (Model $\mathrm{A}-\mathrm{E}$ ). Experiment 2 compares the same models as experiment 1 but with the same wind input to compare the influence of the design to wind speed (Model A - E). Experiments 3 and 4 will discuss the use of Rumbak Tahansengan, experiment 3 compares the influence of Rumbak Tahansengan on the original building of 1933 (Model E \& F), while experiment 4 will discuss the application of Rumbak Tahansengan in today's buildings (Model A \& G).. The classification of the discussion will be explained in Table V.

\begin{tabular}{|c|c|c|c|c|c|}
\hline $\mathrm{T} F$ & MODEL DAN EXPEF & ENT & AS & ATI & \\
\hline \multirow{2}{*}{ Model } & \multirow{2}{*}{ Period and description } & \multicolumn{4}{|c|}{ Experiment } \\
\hline & & 1 & 2 & 3 & 4 \\
\hline $\mathrm{A}$ & 2014 (existing) & $\sqrt{ }$ & $\sqrt{ }$ & & $\sqrt{ }$ \\
\hline $\mathrm{B}$ & 1991 & $\sqrt{ }$ & $\sqrt{ }$ & & \\
\hline $\mathrm{C}$ & 1983 & $\sqrt{ }$ & $\sqrt{ }$ & & \\
\hline $\mathrm{D}$ & 1938 & $\sqrt{ }$ & $\sqrt{ }$ & & \\
\hline $\mathrm{E}$ & 1933 & $\sqrt{ }$ & $\sqrt{ }$ & $\sqrt{ }$ & \\
\hline $\mathrm{F}$ & $\begin{array}{l}1933 \text { with Rumbak } \\
\text { Tahasengan }\end{array}$ & $\sqrt{ }$ & $\sqrt{ }$ & $\sqrt{ }$ & \\
\hline G & $\begin{array}{c}\text { Existing with application of } \\
\text { Rumbak Tahansengan }\end{array}$ & & & & $\sqrt{ }$ \\
\hline & Wind speed : & $\mathrm{F}$ & $\mathrm{C}$ & $\mathrm{C}$ & $\mathrm{C}$ \\
\hline
\end{tabular}

$\mathrm{F}=$ Fluktuate (wind speed according to model's period)

$\mathrm{C}=$ Constant (current wind speed)

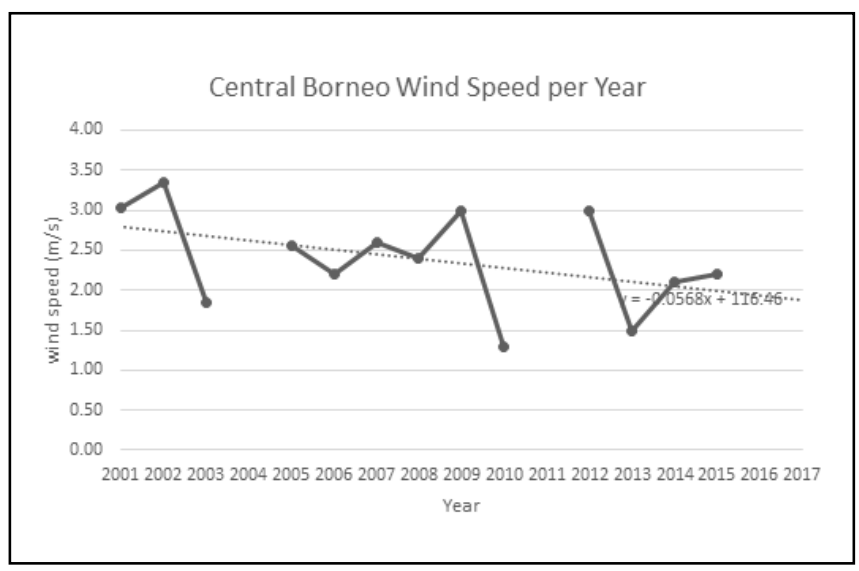

Fig. 2. Central Borneo Wind Speed per Year

Macro data from 2001 to 2015 is needed to indicate the wind speed in certain year. Fig. 2 shows that wind speeds in the past few years are faster than the current wind speeds. That is likely due to the development of cities and regions that cause the increase in wind obstruction. Based on the Fig. 2 we can estimate the wind speed in the years before 2001 , especially in $1933,1938,1983$, and 1991 according to the period of the experimental model. 
The calculation for wind speed values is obtained by comparing the macro and field measurement data. The field show a wind speed of $0.15 \mathrm{~m} / \mathrm{s}$ of outdoor buildings with wind direction from the North. The outdoor wind speed is then calculated by the power law formula [9] based on the terrain roughness of the area to obtain a freestream wind speed (friction).

In the experiment 1 , the wind speed will be adjusted according to the wind speed in the period when the model was built (Table IV).

TABLE VI. WIND SPEED ACCORDING TO PERIOD

\begin{tabular}{|c|c|c|c|c|}
\hline Model & Periode & $\begin{array}{c}\text { Weather } \\
\text { Base } \\
\text { velocity } \\
(\mathrm{m} / \mathrm{s})\end{array}$ & $\begin{array}{c}\text { Freestreamw } \\
\text { ind speed at } \\
300 \mathrm{~m} \\
(\mathrm{~m} / \mathrm{s})\end{array}$ & $\begin{array}{c}\text { wind speed } \\
\text { for } \\
\text { simulation } \\
\text { input }(\mathrm{m} / \mathrm{s})\end{array}$ \\
\hline A & 2014 & 2.06 & 3.44 & 0.15 \\
\hline B & 1991 & 3.37 & 5.62 & 0.24 \\
\hline C & 1983 & 3.83 & 6.37 & 0.28 \\
\hline D & 1938 & 6.38 & 10.63 & 0.46 \\
\hline E & 1933 & 6.67 & 11.10 & 0.48 \\
\hline
\end{tabular}

Simulation rsults are observed in the position of the section line where the $\mathrm{A}^{\prime}$ opening acted as inlet and $\mathrm{A}$ as outlet. The Layout plan that have section line for output result can be seen in Fig. 3 .

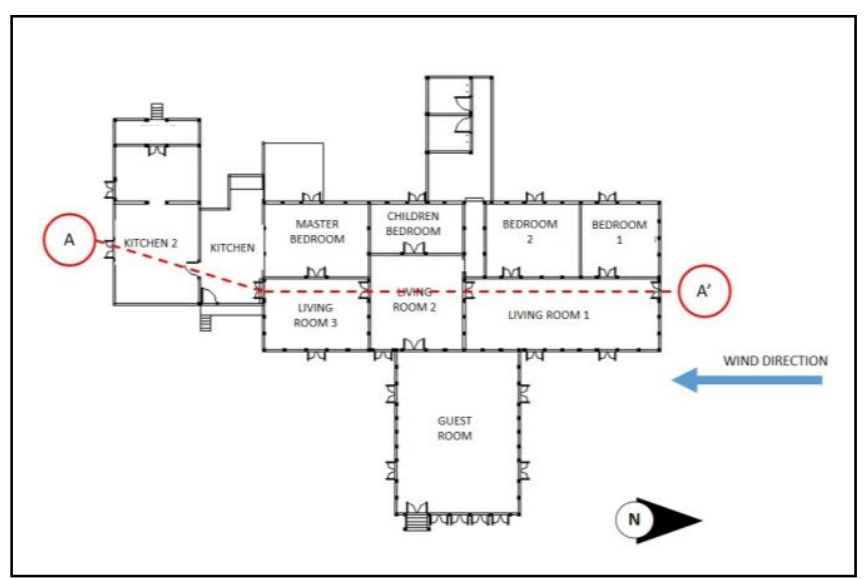

Fig. 3. Layout plan

\section{RESULT}

\section{A. Experiment 1: Adaptation}

Fig. 4 shows that wind speed decrease occurs in all models. With different speeds it can be seen that the five models have similar wind speed patterns. The wind speed from the inlet to the living room decrease around $60-70 \%$ in the center of the room (Fig. 5) then increases on the outlet door to another room about $30-50 \%$ and decrease again. The low wind velocity in the middle of the room is caused by the movement of the wind that has entered the terminal region phase where the wind loses pressure, and become stable because it has already blend into the air in the room. This phase occurs due to friction against the partition walls in the building, that cause the lost of air pressure [13].

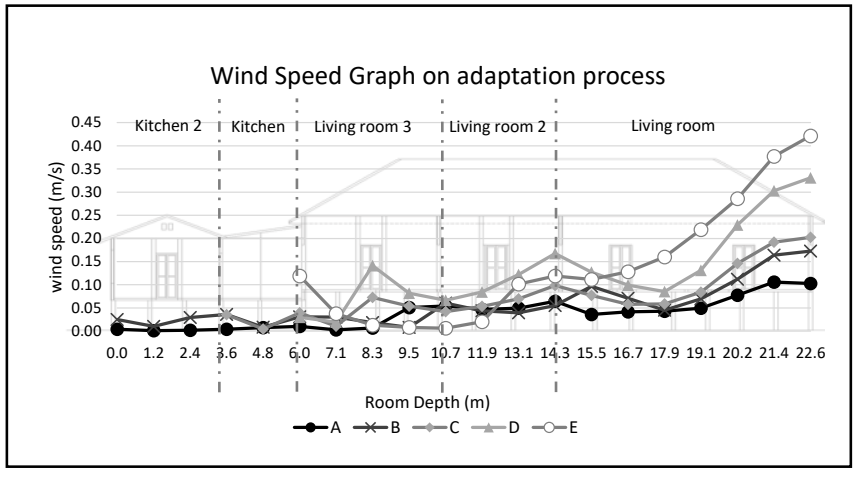

Fig. 4. Wind Speed Graph on adaptation process

Fig. 5 demonstrates that the model $\mathrm{E}$ has a very high air change compared to the other model. This because of higher wind speed and the absence of ceilings in the room so that the volume of space inside the room increases. The increase of the roof volume is accompanied by the increase of openings. This happens because the wall of the room is only raised to a height of $3.1 \mathrm{~m}$ so that the roof space does not have a dividing wall between one room and another. The absence of this separating wall is then assumed to be an increase the area of openings, both inlet and outlet depending on the wind direction in the chamber.

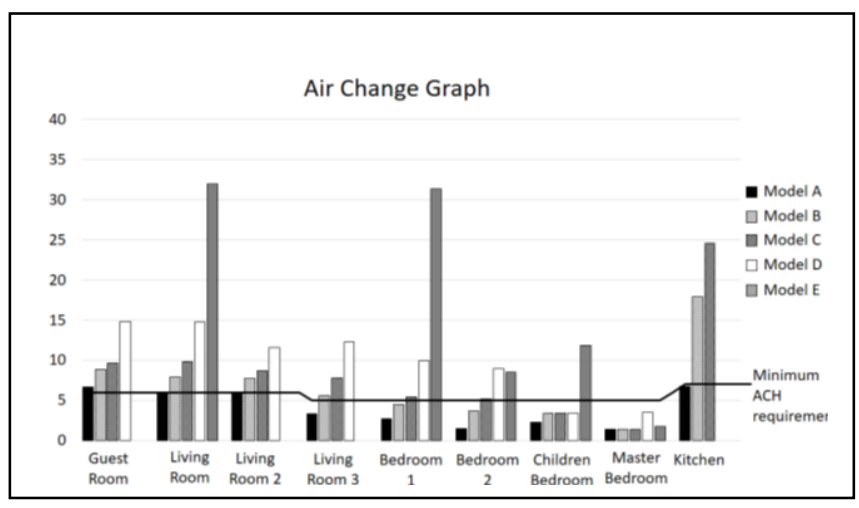

Fig. 5. Air Change Graph on adaptation process

Fig. 6 also shows that bedroom, which is at the west side, have no opening that facing the wind direction. The opening locate at the leeward site at building. It result the low ACH value that does not meet the minimum requirement.

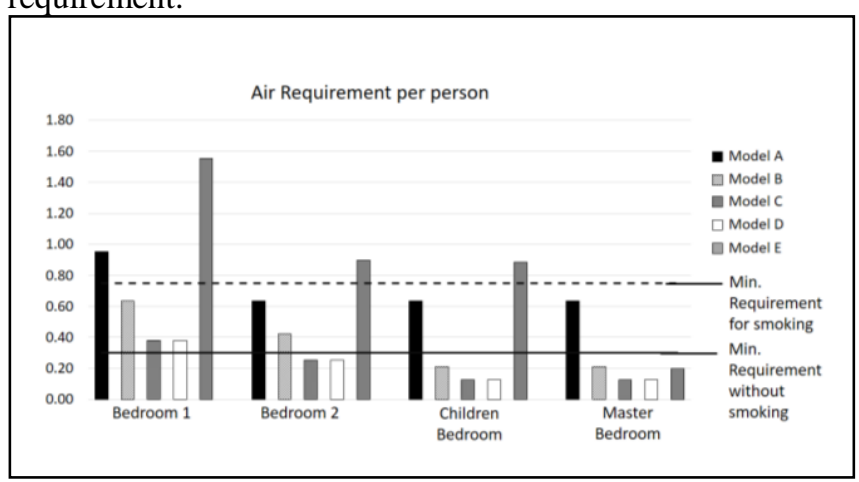

Fig. 6. Air Requirement per person 
Health aspects not only can be assessed using $\mathrm{ACH}$, but also from the air rate per person. ACH only evaluates the air change per room, while the requirement of air rate that has been listed on SNI 03-6572-2001 besides the standard per room also includes the requirement of air exchange rate for each person.

Fig. 6 show that model $\mathrm{A}$ is the best model, eventhough in Fig. 5 has the smallest ACH. Models C and D are the most unhealthy bedroom models, due to the fact that during this period there were addition of family members, but wind speed was lower than the previous year.

\section{B. Experiment 2: Design Comparison}

This experiment discussed about the changes that affect the pattern and speed of wind in the room. The wind input in this experiment is adjusted to the current wind speed of 0.15 $\mathrm{m} / \mathrm{s}$.

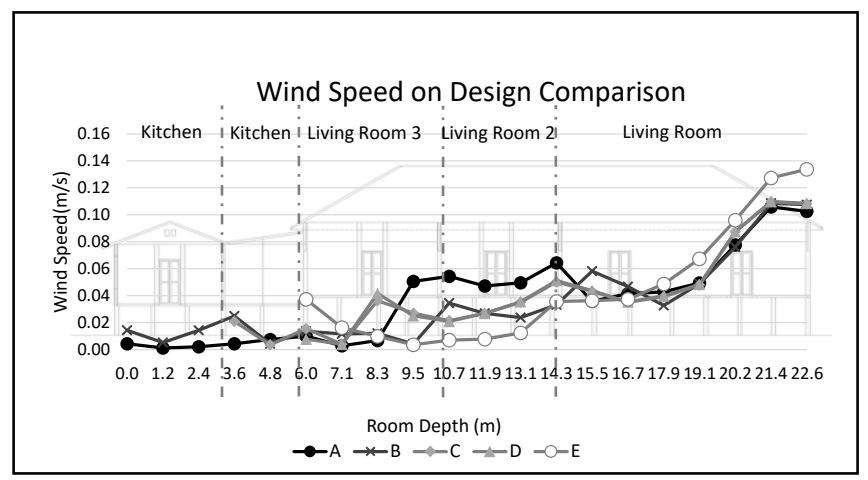

Fig. 7. Wind Speed Graph on Design Comparison

Just as in the previous experiment, the wind speed from the inlet to the living room dropped about $60-70 \%$ in the center of the room then increased at the outlet door to another room about $30-50 \%$ and decreased again. With the same input speed it can be seen that in the middle of the room the highest velocity is found in model A (coordinates 9.5 - 14.3). This happens because there is a connecting space to the bathroom that is not found in other models, resulting in narrower space causing the increase of wind speed.

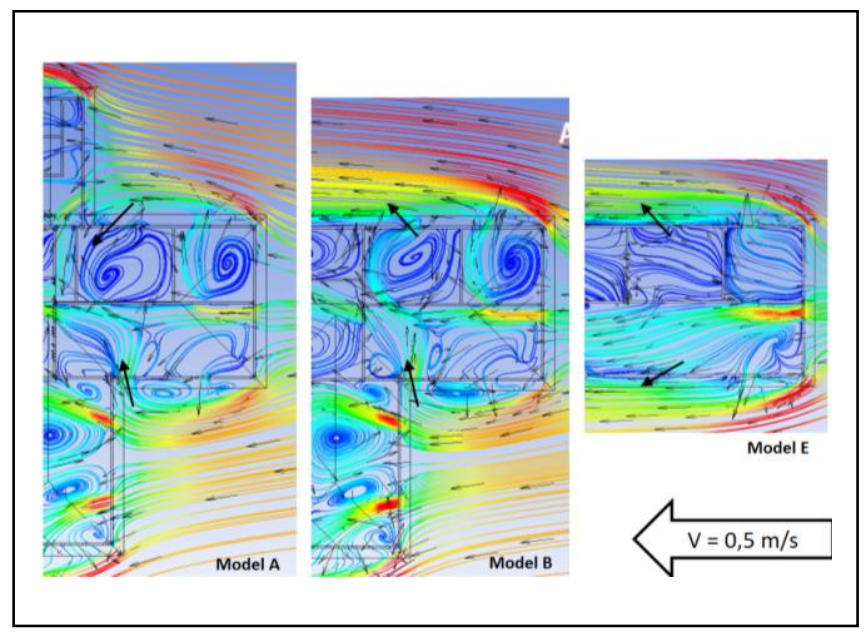

Fig. 8. Function shift at openings
The addition of a room within a building has a certain impact in terms of natural ventilation. The wind that hit the dividing wall will be diffused and look for a new direction to flow. This also happened to Betang House with the addition of guest room and new bathroom. For comparison, the models $\mathrm{A}, \mathrm{B}$, and $\mathrm{E}$ have a change in form of the addition of space on the leeward side resulting in positive pressure on the side of the building [14]. This affects the direction of the incoming and outgoing winds, determining openings in buildings as inlets or outlets.

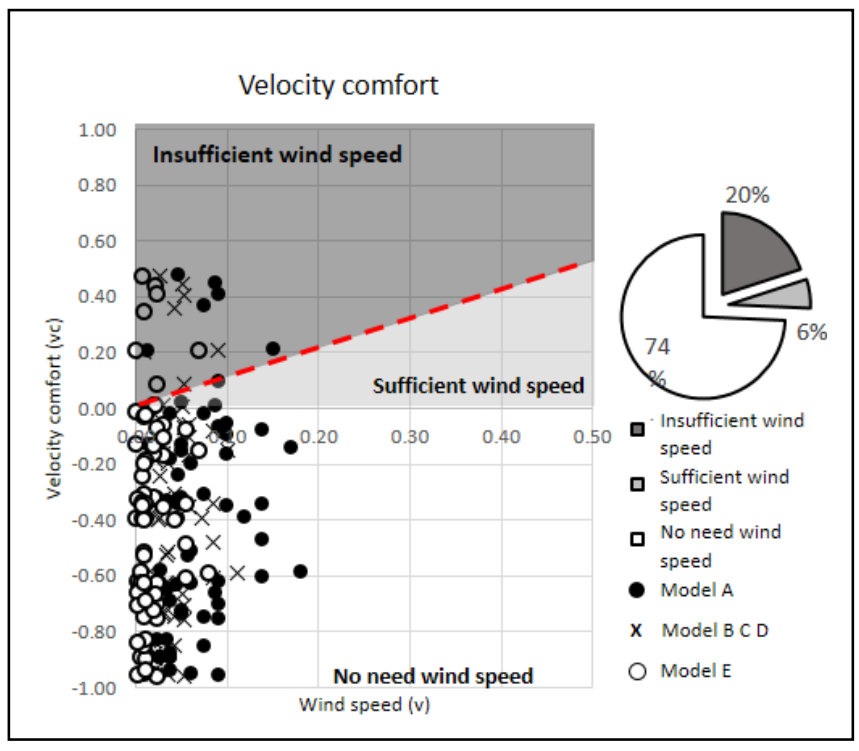

Fig. 9. Velocity comfort

On the comfort aspect, the five models are compared by considering the wind needs at Betang Djaga Bahen House. The determination of the simulation point is carried out in a fixed room that didn't undergo a change during the 5 times the period of change, and is the midpoint of the A-A ' cutline. In this velocity comfort experiment, wind velocity measurement is done in the room for $3 \times 24$ hours. Fig. 9 shows the scatter chart of the required speed of wind per hour. Based on the figure, it can be seen that although it has different values, the spread between no need of air movement, wind speed that is fulfilled and wind speed that is not fulfilled on all models are the same. As much as $74 \%$ did not require air movement for physiological cooling, $6 \%$ need air movement for physiological cooling and was fulfilled, even if the remaining $20 \%$ needed air movement but not fulfilled

\section{Experiment 3: Rumbak Tahansengan Potency}

The third experiment was try to see the purpose of the opening on the gevel, Rumbak Tahansengan. This opening is 2 pieces of holes sized $30 \times 15 \mathrm{~cm}$ which are located on the gevel of the building with a gable roof. In this experiment the original model of the house Betang will be used, which stood in 1933. The model will be given 2 different treatment: the original state (E) with Rumbak Tahansengan and without Rumbak Tahansengan (F).

Fig. 10 shows that the difference in wind velocity is only about $0.01 \mathrm{~m} / \mathrm{s}$. This shows that when area of Rumbak Tahansengan are maintaned in their original conditions, 
wind speed does not have a significant effect. The traditional opening of Rumbak Tahansengan, in accordance with its original form, can not affect the wind speed significantly, because the opening area is too small so it does not have much effect on the wind coming into the room in a wind driven way.

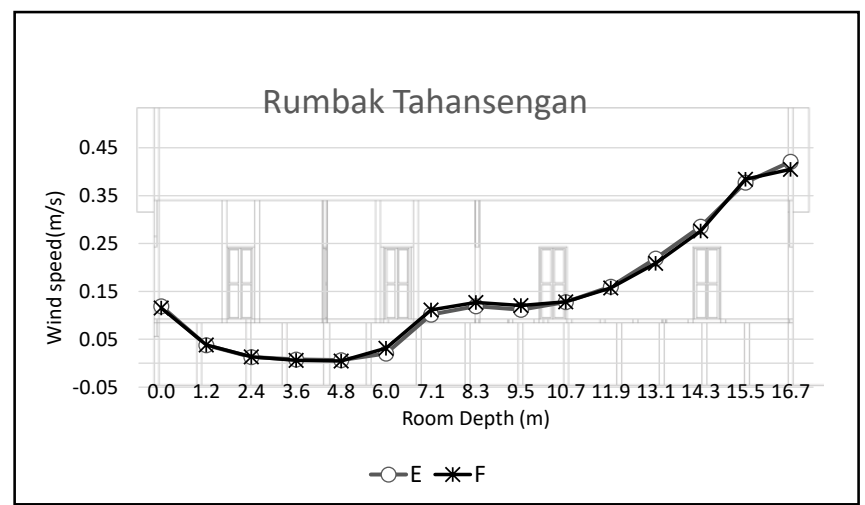

Fig. 10. Wind Speed Graph on Design Comparison

\section{Experiment 4: Rumbak Tahansengan Application}

The following experiment will discuss the use of Rumbak Tahansengan in the current building model (model A). The application of Rumbak Tahansengan in the building in current form is followed by the change of the roof model from pitch roof to gable roof, because the location of Rumbak Tahansengan is on the gevel of the building. It also affects inside the room where there is no ceiling as a separator with roof space.

Fig 11 shows that the $\mathrm{G}$ model has higher wind speeds in both the inlet and outlet of the building but lower in the middle of the room compared with model A. This indicates that the wind distribution in the $\mathrm{G}$ model is better than the model $A$, the wind velocity fluctuation in the $G$ model is lower than the model $\mathrm{A}$. This is due to the existence of the ceiling space so the openings in the room increases. Additional openings, either inlet or outlet, cause a lower air pressure difference so that wind speed will enter the regional terminal phase faster [13].

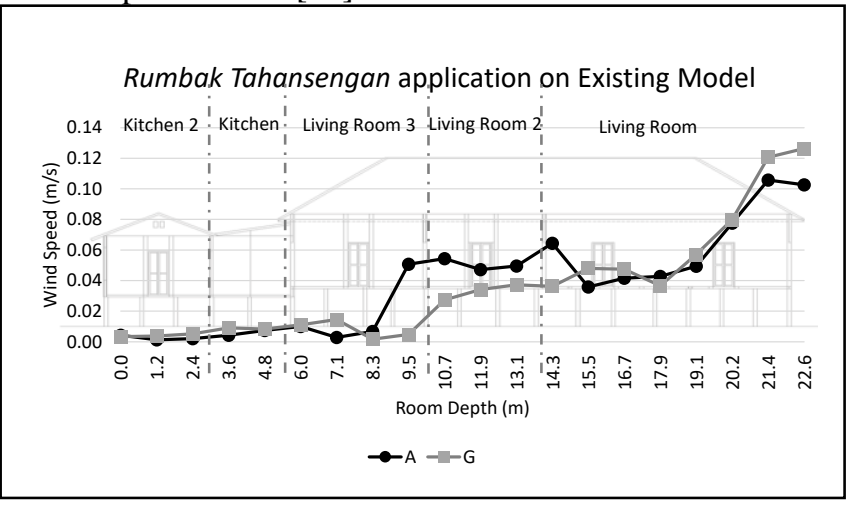

Fig. 11. Wind Speed Graph on Design Comparison

Based on the discussion of experiment 3 it can be said that the Rumbak Tahansengan is not effective to increase air movement, instead, volume change due to the absence of ceiling will cause change in $\mathrm{ACH}$ value inside the room (ACH comparison in Fig. 13). This is due to changes in the volume and change of the inlet and outlet area of the room, and those two elements of the building are variables to determine the value of $\mathrm{ACH}$ in the building. The volume the $\mathrm{ACH}$ value of the room, the larger building volume the greater the $\mathrm{ACH}$ value and vice versa, this is because volume is also needed to calculate the airflow to fill the space [16].

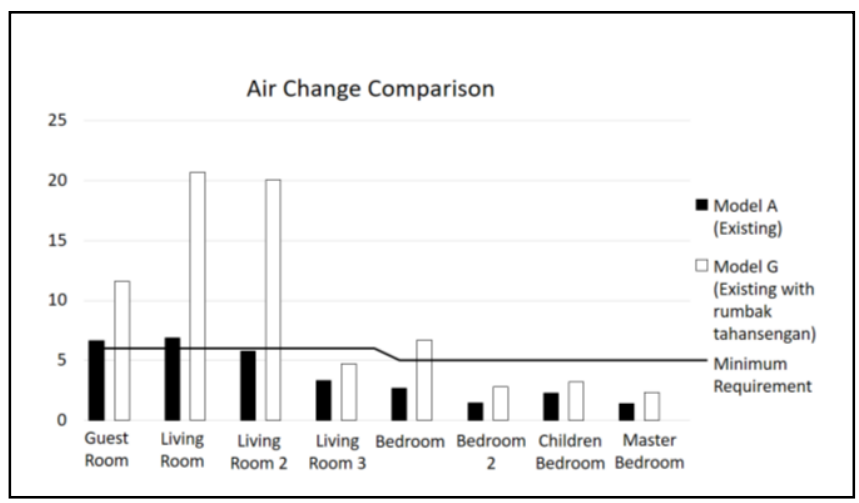

Fig. 12. Air Change per hour comparison

\section{DISCUSSION}

Based on the experiment and simulation results above, conclusions related to the performance of natural ventilation at Betang Djaga Bahen House can be drawn. These include:

- The wind speed from the inlet enters the chamber drops about $60-70 \%$ then increases at an outlet for about 30$50 \%$. The low value of wind velocity in the middle of the room is caused by the movement of the wind that has entered the terminal region phase where in that phase the wind loses pressure so that its speed becomes stable because it has already integrated with the air in the room [13].

- The addition of space may result in a change of inlet function into an outlet or vice versa, this is because the wall raised for space addition can be considered as a wing walls that can affect air pressure outside the room [14]. Wing walls can also improve natural airways by increasing $\mathrm{ACH}$ and average speed in space [15]

- In the adaptation process from 1933 to present, regarding on $\mathrm{ACH}$, the number of occupants must be taken into account. It is necessary to know the needs of the air rate of each person in a particular room. In Betang Djaga Bahen House, although the $\mathrm{ACH}$ value of model $\mathrm{A}$ is the smallest, but the rate of wind requirement per person is the best because of the smaller number of occupants.

- In terms of comfort, based on simulation results, the five models of Betang Djaga Bahen House can still be said to be comfortable, because about $80 \%$ of needs for the physiological cooling have been met.

- Rumbak Tahansengan opening can not increase the wind velocity in the room significantly $(>0.01 \mathrm{~m} / \mathrm{s})$ because Window Wall Ratio (WWR) only increases by about $0.2 \%$. Although less functional, the openings result in volume changes due to the absence of elements. This is due to changes in the volume and change of the inlet and outlet area of the room, and those two elements of the 
building are variables to determine the value of $\mathrm{ACH}$ in the building. The volume the $\mathrm{ACH}$ value of the room, the larger building volume the greater the $\mathrm{ACH}$ value and vice versa, this is because volume is also needed to calculate the airflow to fill the space [13\6]

- $\quad$ The application of Rumbak Tahansengan in the building model A (present time) causes the roof shape to change from pitch roof to gable roof and remove the ceiling as a barrier of roof space. This results in the increase of the opening area of the room. Additional openings, either inlet or outlet, cause a lower air pressure difference so that wind speed will enter the regional terminal phase faster [13].

\section{CONCLUSION}

In the process of adaptation of the change of Betang Djaga Bahen House from 1933 until today, the number of occupants of the house is one of the factors that affect the comfort in the room. This is intended to determine the need of air rate for each person in the room. Large $\mathrm{ACH}$ can not be the standard if the occupancy rate exceeds the usual occupancy level. Bedrooms are usually occupied a maximum of 2 people, in past Betang Djaga Bahen House, 1 room can be occupied by 1 family (about 4-5 people). Therefore model A (current period) has a better rate of air per person than models in the previous period although the wind speed that goes into the house is smaller.

In the past there was also a traditional opening called Rumbak Tahansengan. In its the original shape, it can not affect the air movement significantly because the opening area is too small $(0.2 \%$ WWR addition) so it does not have much effect on the wind driven into the room. In the application of Rumbak Tahansengan, the factors causing changes in the flow and speed of the wind is the form of the gable roof and the absence of the ceiling. The gable roof causes the gevel to face the wind direction (windward) so that it affects the air pressure. While the absence of a ceiling as a barrier to the roof space causes the opening in the room to increases, and the addition of openings, either inlet or outlet, cause a lower air pressure difference so that wind speed will enter the regional terminal phase faster.

\section{ACKNOWLEDGMENT}

The author would like to say many thanks to Research Station for Housing on Region II Denpasar (Balai Penelitian dan Pengembangan Perumahan Wilayah II Denpasar Kementerian PUPR), which has been supporting to get the field of measurement data used in this paper in Palangka Raya, Central Borneo, Indonesia in 2014.

\section{REFERENCES}

[1] Fitriaty, P., Antaryama, I.G.N., and Ekasiwi, S.N.N., (2011), Thermal Performance of Traditional House in the Upland Central Celebes of Indonesia, IPTEK, The Journal for Technology and Science, Vol. 22, No. 4

[2] Karyono, T.H., Suwantara, I.K., Nugrahaeni, R., Suprijanto, I., and Vale, R., (2012) "Karakteristik Termal pada Uma Lengge di Desa Mbawa Nusa Tenggara Barat", DIMENSI (Journal of Architecture and Built Environment), Vol. 39, No. 1, 5-14, Surabaya.

[3] Alfred, D.D.P.J., Antaryama, I.G.N., and Ekasiwi, S.N.N., (2016), Kinerja Termal Rumah Niang di Dataran Tinggi Tropis Lembab di Distrik Manggarai, ATRIUM, Vol. 2, No. 1, 43-54

[4] Susanti, E., Damayanti, D.P., Ekasiwi, S.N.N., and Defiana, I., (2015) The effect of opening on building envelope toward daylight performance in Betang House at Central Borneo, 8th International Conference on Architecture Research and Design $(\mathrm{AR}+\mathrm{DC})$, ITS, Surabaya

[5] Kristianto, M.A., Utama, N.A., ad Fathoni, A.M., (2014), Analyzing Indoor Environment of Minahasa Traditional House Using CFD, Elsevier, Procedia Environmental Sciences 20 ( 2014 ) 172 - 179

[6] Perkasa, P. (2010), Konservasi Bangunan Bersejarah di Desa Bahu Palawa, Jurnal Perspektif Arsitektur, Vol 5 No 1, Juli 2010, Palangka Raya.

[7] Asteria, (2008), Perkembangan Penataan Interior Rumah Betang Suku Dayak Ditinjau dari Sudut Budaya, "Dimensi Interior", Vol 6. No. 2, 134-148, Universitas Kristen Petra, Surabaya.

[8] Samodra, F.X.T.B., (2017), Analysis of resilient design by thermoacoustic adaptation of tropical urban model, Journal of Architecture and Urbanism, 41:4, 305-315, DOI: 10.3846/20297955.2017.1413960

[9] Allard, Francis, (1998), Natural Ventilation in Buildings: A Design Handbook, James \& James Ltd, London.

[10] Aynsley, R. \& Spruill, M. (1990), Thermal Comfort Models for Outdoor Thermal Comfort in Warm Humid Climates and Probabilities of Low Wind Speeds, "Journal of Wind Engineering and Industrial Aerodynamics, 36, 481-488, Elsevier Science Publisher B.V., Amsterdam.

[11] Mediastika, C.E (2002) "Desain Jendela Bangunan Domestik untuk Mencapai Cooling Ventilation”. Dimensi Teknik Arsitektur, Vol. 30, No.1, Juli 2002:77-84.

[12] Aynsley, R.M., et.al. (1977), Architectural Aerodynamics, Applied Science Publishers, London.

[13] Awbi, H. B., (1991), Ventilation of Buildings, E \& FN Spon, London.

[14] Moore, Fuller, (1993), Environmental Control Systems: Heating Cooling Lighting, McGraw-Hill, Inc., USA.

[15] Mak, C.M., Niu, J.L., Lee, C.T., and Chan, K.F., (2007), A Numerical Simulation of Wing Walls Using Computational Fluid Dynamics, Energy and Buildings 39, 995 - 1002, Elsevier.

[16] Noman, F.G., Kamsah, N., and Kamar, H.M., (2016), Improvement of Thermal Comfort Inside a Mosque Building, Jurnal Teknologi, Faculty of Mechanical Engineering, Universiti Teknologi Malaysia, Johor. 